\title{
ANALYSIS DETERMINANT OF TOURIST DEVELOPMENT IN THE CONTEXT OF OPTIMIZATION OF ITS TAXATION IN UKRAINE
}

Today share of world tourism are equal to or even higher than export of oil, food, or car production. It forms more than $10 \%$ of the world gross domestic product. Analysis of the existed research results related to the topic allows identifying that a number of social, economic, and institutional factors influences the efficiency of tourism enterprises, but taxation processes play a special role. Namely, collection of a tourist tax in European countries comes from the cost of living, which is fairer for tourists. In addition, a number of studies have shown that with an increase in the rate of value-added tax and corporate income tax, the number of visitors decrease. Based on the results of the analysis, a set of potentially relevant factors influencing tourism key performance indicators was formed. The paper identified the strength and direction of their impact on net tourism revenues (difference between inflows and outflows of revenues from tourism) using panel data regression analysis for a sample of countries such as Bulgaria, Austria, Germany, Hungary, Latvia, the Czech Republic, Greece and Ukraine for 2008-2019. This task was realized using Stata software. In order to test the hypothesis it was chosen net international income from tourism as the dependent variable, while inflation (deflator of GDP), GDP per capita, value-added tax payments to total revenue ratio, corporate income tax payments to total revenue ratio, social contribution payments to total revenue ratio, and personal income tax payments to total revenue ratio were chosen as independent variables. Panel data regression analysis allowed confirming the hypothesis about the relevance of the impact of tax factors on tourism development. Taking into account the empirical results, as well as the analysis of world experience, proposals were developed to improve the domestic system of taxation of tourism enterprises. The developed proposals are aimed at improving the taxation system in Ukraine and the development of the domestic tourism business. It is proposed to change the rate and base of tourist fee collection in accordance with the experience of European countries. It is also important to introduce a number of tax benefits for tourism development in the country.

Key words: tourism, income from tourism, tourist fee, regression analysis, panel data.

DOI: https://doi.org/10.32838/2523-4803/70-3-42

УДК 368.013

Горбачова О.М.

кандидат економічних наук, доцент,

Національний авіаційний університет

Tруш I.B.

студентка,

Національний авіаційний університет

Horbachova Oksana, Trush Iryna

National Aviation University

\section{СТРАХУВАННЯ ЖИТТЯ В УКРАЇНІ: ПРОБЛЕМИ І ПЕРСПЕКТИВИ}

Ринок страхування життя в кожній країні є індикатором економіки та сталого розвитку підприємництва. Коли стабільність та добробут краӥни досягає певного рівня, то і прачівники, і роботодавиі починають думати про своє майбутнє, забезпечувати свою старість, фінансувати ризики, які існують у житті кожної людини. Стрімке старіння населення всіх країн світу виснажує фінансову спроможність громадян, щзо призводить до низького рівня охорони здоров'я та пенсійного забезпечення. Страхування життя дає змогу забезпечити щзоденний захист людини - як сьогодні, так $i$ в майбутньому. Це приводить до виникнення двох ефектів: у держави з'являються додаткові довгострокові кошти, які забезпечують фінансування інвестиційних проектів, щзо сприяє подальшому розвитку економіки краӥни; громадяни отримують страховий захист, накопичення на майбутні періоди та захист їхніх інтересів. Ринок страхування життя в Україні перебуває на етапі формування. Основними перешкодами і проблемами його розвитку є нестабільна соціально-економічна ситуація на сучасному етапі та особливості культурно-історичних традицій украӥнського суспільства.

Ключові слова: ринок страхування, страхування, страхування життя, сочіальна система, тенденції, динаміка.

Постановка проблеми. Зміни, які відбуваються в українському суспільстві, політичні, економічні і соціальні перетворення зумовлюють важливість посилення уваги до страхового захисту суспільства. Насамперед ефективних важелів та механізмів впливу потребує накопичувальне страхування, оскільки динаміка 
цього виду страхових відносин впливає на добробут населення ісоціально-економічну стабільність населення. Тенденції ринку страхування життя визначають потребу виявлення чинників, що гальмують його розвиток, і необхідність пошуку рішень для їх подолання. Зазначене дає змогу стверджувати про актуальність дослідження проблем і перспектив розвитку страхування життя в Україні.

Аналіз останніх досліджень і публікацій. Дослідженню страхування життя, його специфіки, тенденцій та розвитку присвячені праці таких учених, як: В. Базилевич, О. Гаманкова, О. Залєтов, Ю. Клапків, I. Козьма, Л. Куделя, Г. Кулина, Я. Медвідь, Л. Приступа, О. Радецька, Т. Стецюк, О. Фарат та ін. [1].

Питаннями страхування життя займаються такі зарубіжні науковці, як В. Гаркуша, В. Горін, Ж. Монкієвич, Т. Назлоян, М. Піккард, М. Попов, В. Райхер, Т. Санговськієжо, Б. Сербіновський, В. Тулінов, В. Шахов, Р. Юлдашев та ін.

Однак не досить вивченими залишаються проблеми поєднання страхового та пенсійного забезпечення населення України, потребує удосконалення страхування життя в Україні, що і зумовило необхідність їх подальшого дослідження. Недостатній рівень теоретичних розробок та необхідність вирішення проблем удосконалення законодавчої бази страхування життя, активізації інвестиційної діяльності страховика, збалансування інтересів страховика i страхувальника зумовлюють актуальність теми дослідження.

Формулювання цілей статті. Метою роботи $\epsilon$ дослідження ринку страхування життя в Україні, визначення його стану, а також пошук шляхів розвитку і вдосконалення його становлення.

Виклад основного матеріалу. Страхування життя важливий елемент соціальної системи держави, засіб захисту рівня добробуту населення і забезпечення стабільності економічного розвитку, а також досить могутнє джерело внутрішніх інвестицій. «Страхування життя - вид особистого страхування, який передбачає обов'язок страховика здійснити страхову виплату згідно з договором страхування у разі смерті застрахованої особи, а також, якщо це передбачено договором страхування, у разі дожиття застрахованої особи до закінчення строку дії договору страхування та (або) досягнення застрахованою особою визначеного договором віку» [2] - так трактує досліджуваний вид відносин чинне законодавство.

Ринок страхування життя в Україні почав своє становлення у 1996 році, після набуття чинності Законом України «Про страхування», де страхування життя виділялось як окрема галузь страхової діяльності. Становлення цього виду відносин продовжується і донині.

Страхова діяльність змінюється, розвивається і все більше впливає на економіку країни, розширюється сфера страхування, з'являються та розвиваються нові його види. Дослідники відзначають, що галузь страхування до настання світової фінансово-економічної кризи за темпами розвитку випереджала інші галузі економіки. Зокрема, в період із 2001 р. до 2008 р. темп росту валових страхових надходжень у середньому по страховому ринку становив 134,4\%. Водночас «середньорічні темпи росту надходжень по ринку страхування життя дорівнювали 183,4\%» [3, с. 116].

Характерними ознаками сучасного страхового ринку Үкраїни є нестабільні тенденції його розвитку. Оцінка найважливіших макроекономічних показників страхової галузі засвідчує, що вітчизняний страховий ринок так і не подолав наслідки фінансово-економічної кризи, яка розпочалася у 2008 р. Тож для українських страхових компаній (СК) період, яий зазвичай називають посткризовим, на думку дослідників, можна визначити як «перехід кризи від гострої до латентної форми». В Україні не було належним чином усвідомлено, що негативні явища в розвитку цього ринку мають не циклічний, а системний характер

Втрати страховиків, які займаються страхуванням життя, під час криз більші порівняно 3 іншими суб'єктами економіки. Це пов'язано з особливостями досліджуваного виду економічних відносин: вразливістю до стагнаційних процесів і спрямованістю на довготривалу перспективу.

Діяльність СК, які надають послуги із страхування життя, неможлива без стабільного стану національної і світової економіки, а низький рівень розвитку фінансового ринку та його нестабільність зменшує ефективність страхування та навіть спричинює його недоцільність.

Кількість СК, що займаються страхуванням життя, значно поступається кількості компаній, що здійснюють інші види страхування. Зокрема, у 2016 р. останніх було майже у 7 разів більше. При цьому порівняно iз 2011 p. кількість CK «life» зменшилась більш ніж на третину: станом на кінець 2016 р. на ринку страхування життя функціонувало 39 таких установ, а станом на 30.09.2017 р. - 34 компанії, тобто зменшилася від початку року на 5 компаній. Темпи зниження кількості страховиків, які займаються іншими видами страхування, є дещо нижчими та становлять 28,3\%. Водночас кількісний аналіз СК у докризовий період, тобто до 2008 р., засвідчує швидку динаміку зростання кількості установ, що спеціалізуються на страхуванні життя. Тенденція щодо зменшення їх кількості спостерігається 3 2010 р. Нині кількість «life»-компаній менша, ніж у 2004 році. Як показують дослідження, на ринку припиняють свою діяльність ті страховики, рівень капіталізації яких не відповідає встановленим нормативам, або ті, які займалися не «класичним» страхуванням.

Згідно з даними Нацкомфінпослуг, у 2016 р. ННІ на ринку страхування життя становив 1079,59 (у 2015 р. 982,98)[4]. Такаситуаціяспричиненанезадовільнимфінансовим станом значної кількості страхових компаній.

Аналіз динаміки кількості застрахованих осіб згідно 3 договорами страхування життя у 2008-2016 рр. відображає, що цей сегмент страхового ринку зазнав значних втрат у 2009 р. і в 2010 р., коли темпи зниження кількості застрахованих осіб сягнули відповідно -7,6\% та $-7,1 \%$. Та найбільше скорочення кількості застрахо- 
ваних осіб (близько 774 тис. осіб) мало місце у 2016 р., темпи зниження досягли максимального значення та становили $-15,7 \%$.

При цьому, крім зменшення загальної кількості застрахованих, намітився спад застрахованих упродовж року (на $11,0 \%$ ): протягом року застраховано 1,38 млн фізичних осіб проти 1,55 млн осіб за відповідний період 2015 р. Таким чином, зусилля страховиків щодо утримання клієнтів виявилися неефективними.

Страхові компанії продовжують зазнавати значних збитків внаслідок дострокового розривання укладених договорів (у 2016 p. 13 СК отримали від'ємне значення приросту резервів зі страхування життя).

Нинішня важка економічна ситуація не дає можливості державі у повному обсязі задовольняти потреби громадян у медичному обслуговуванні, відшкодуванні фінансових витрат у разі травматизму на виробництві чи втрати працездатності і вирішувати інші соціальні питання.

Передбачене соціальними стандартами забезпечення недостатнє для покриття вже існуючої фінансової уразливості [5, с. 134]. Страхування життя покликане розв'язати подібні проблеми.

Використанню послуг страхування життя як вагомого і комплексного інструменту соціального захисту сприятимуть: просвітницька діяльність страхових компаній, оскільки більша частина потенційних страхувальників не проінформована чи проінформована погано про послуги, котрі надаються страховиками, а також про соціальні та економічні вигоди, які може принести страхування для кожного громадянина зокрема; розширення списку професій, спеціальностей та посад, що підлягають обов'язковому страхуванню життя; обов'язкове страхування життя військовослужбовців, медиків, волонтерів та інших учасників антитерористичної операції; розширення переліку страхових випадків у «life»-страхуванні; спрощення процедури укладання договору страхування життя, інтеграція цього виду страхування до системи онлайн-послуг, популяризація укладання страхових угод через Інтернет.

Зростає необхідність у запровадженні інструментів, які б захищали страхові внески страхувальників від інфляції. Однією із причин непопулярності страхування життя в Україні $\epsilon$ те, що інфляційні процеси невпинно зменшують реальну вартість страхових виплат.

Розв'язати цю проблему допоможе запровадження на законодавчому рівні індексації страхових виплат чи прикріплення страхових операцій до більш стабільних грошових одиниць. Страхове законодавство $є$ вирішальним чинником у формуванні політики страхування ризиків, пов'язаних із життям, воно визначає «правила гри» для суб'єктів страхової діяльності, порядок надання послуг, методи державного регулювання. В Україні страхове законодавство розроблене досить повно, та все ж таки потребує удосконалення, змін і доповнень.

До першочергових завдань у сфері державного регулювання страхової діяльності слід віднести опти- мізацію податкового законодавства у сфері страхування життя. Насамперед йдеться про необхідність запровадження стимулів податкового характеру, які спонукатимуть фізичних і юридичних осіб до придбання полісів страхування життя.

Для покращення платоспроможності та забезпечення необхідного рівня достатності капіталу страхових компаній необхідно звернутися до методологій, які розроблені Європейським Союзом, зокрема запропонованих у Директиві Європейського Парламенту та Ради 2009/138/€C (Solvency II) [6], та адаптувати їх для вітчизняного страхового ринку. Це сприятиме посиленню рівня відповідальності страхових компаній перед клієнтами та дасть змогу максимально використовувати їхній фінансовий потенціал як потужних інституційних інвесторів в економіку України.

Перспективність ринку страхування життя зросте, якщо держава розробить і впровадить механізм надання допомоги страховим компаніям, котрі опинилися на межі банкрутства. Такі дії зроблять страхову систему більш стабільною, що позитивно позначиться на загальній кон'юнктурі ринку. На рівні держави необхідно розробити заходи, що спрямовуватимуться на розв'язання проблем монополізації ринку страхування життя

Для забезпечення зростання лайфового страхування необхідно розвивати перестрахову діяльність. Розвинене перестрахування надає ринку стійкості і підвищує привабливість компанії в очах пересічного покупця страхових послуг. В Україні більшість перестрахових операцій здійснюється іноземними страховими компаніями, така ситуація має свої вигоди та недоліки. Тому зростає необхідність у розвитку вітчизняних страхових компаній, які б надавали послуги перестрахування.

Позитивні зрушення у сфері страхування життя залежать не лише від зазначених заходів, а й від економічної та політичної ситуації, яка склалася в Україні сьогодні. Страхування життя $є$ одним з найбільш перспективних напрямів страхового ринку, воно має стати потужним механізмом розвитку вітчизняної економіки.

Важливе значення страхування життя зумовлює необхідність модернізації цієї сфери та визначення перспектив розвитку. Зростанню ефективності ії функціонування в нашій країні сприятимуть: запровадження системи гарантування страхових виплат за договорами страхування життя; створення галузевої організації (бюро) зі страхування життя; оптимізація податкового законодавства, зокрема запровадження стимулів податкового характеру, що спонукатимуть страхувальників до придбання полісів страхування життя; удосконалення підходів до державного регулювання та нагляду за станом капіталу страховиків та його структурою відповідно до європейської практики (адаптація вимог директиви $\mathrm{EC} \mathrm{Solvency} \mathrm{II);} \mathrm{оптимізація} \mathrm{струк-}$ тури розподілу акумульованих страховиками коштів; запровадження нових страхових продуктів, прогресивних прийомів ризик-менеджменту; підвищення рівня кваліфікації працівників страхових компаній тощо. Передумовою подальшої активізації розвитку ринку 
страхування життя $є$ макроекономічна стабілізація та зростання рівня життя населення, створення умов для активізації інвестиційної діяльності страховиків.

Висновки. Розвиток страхування життя в Україні зумовлює пошук напрямів його удосконалення. Недостатній рівень статутних фондів страховиків не дає змоги забезпечити виконання законодавства під час вступу України в СОТ, тому наведено розрахунки та рекомендації щодо підвищення розміру статутного капіталу страховиків. Не досить дослідженою залишається проблема пенсійного забезпечення через програми довгострокового страхування життя у страхових компаніях на загальнообов'язковому рівні. 3'ясовано низку переваг приватного накопичення у страхових компаніях перед Накопичувальним фондом. Доведено, що умови та показники діяльності страхових компаній перевищують показники недержавних фондів. Накопичувальні фонди тільки починають створюватись, а страхові компанії зі страхування життя працюють на ринку багато років, що підтверджується кількістю клієнтів, прибутком компаній. Запропоновано розширити напрями інвестиційної діяльності та детальніше вивчити інвестиційну діяльність у сфері депозитних вкладів у банківських установах.

\section{Список літератури:}

1. Базилевич В.Д. Новітні тенденції та протиріччя на страховому ринку України. Вісник Київського національного університету імені Тараса Шевченка. Економіка. 2012. № 133. С. 5-8.

2. Про страхування : Закон України від 07.03 .1996 р. № 85/96// Верховна Рада України. URL : http://zakon3.rada.gov.ua/laws/show/85/96-вр (дата звернення 23.02.2020).

3. Чвертко Л.А. Тенденції розвитку страхування життя в Україні в умовах економічної нестабільності. «Сталий розвиток 2030: економічна, сочіальна, екологічна та політична складові» : матеріали доповідей міжнародної міждисииплінарної конференції (Грузія, Тбілісі, 2017). Тбілісі-Львів, 2017. С. 116-121.

4. Клапків Ю.М. Аналіз інституціонального розвитку ринку страхування життя в Україні. Науковий вісник Херсонського державного університету. Серія: Економічні науки,Херсон. 2017. № 25. С. 131-134.

5. Directive 2009/138/EC of the European parliament and of the council of 25 November 2009 on the taking-up and pursuit of the business of Insurance and Reinsurance (Solvency II) (recast) (Text with EEA relevance).

\section{References:}

1. Bazilevich V. D. (2012) Novitni tendenciyi ta ppotipichchya na ctpahovomy pinky Ykpayini [The latest trends and trends in the pink market]. Vicnik Kiyivckogo nacionalnogo ynivepcitety imeni Tapaca Shevchenka. Ekonomika, vol. 133, pp. 5-8.

2. Ppo ctpahyvannya : Zakon Ykpayini vid 07.03.1996 p. № 85/96-VP [Insurance: Law of Ukraine of March 7, 1996 p. № 85/96]. Verkhovna Pada Ukrainy. Available at: http://zakon3.rada.gov.ua/laws/show/85/96-vp (accessed 23.02.2020)

3. Chveptko L.A. (2017) Tendenciyi pozvitky ctpahyvannya zhittya v Ykpayini v ymovah ekonomichnoyi nectabilnocti [Trends in life-sustaining life expectancy in Ukraine in the face of economic instability]. Ctalij pozvitok 2030: ekonomichna, cocialna, ekologichna ta politichna ckladovi : matepiali dopovidej mizhnapodnoyi mizhdicciplinapnoyi konfepenciyi (Gpyziya, Tbilici), vol. 38, no.22, pp. 116-121.

4. Klapkiv Yu.M. (2017) Analiz inctitycionalnogo pozvitky pinky ctpahyvannya zhittya v Ykpayini [An analysis of the intitial call of life in Ukraine]. Naykovij vicnik Hepconckogo depzhavnogo ynivepcitety. Cepiya: Ekonomichni nayki, vol. 25, no. 2, pp. 131- 134 .

5. Directive 2009/138/EC of the European parliament and of the council of 25 November 2009 on the taking-up and pursuit of the business of Insurance and Reinsurance (Solvency II) (recast) (Text with EEA relevance). Official journal of the European Union. - 17.12.2009.

\section{СТРАХОВАНИЕ ЖИЗНИ В УКРАИНЕ: ПРОБЛЕМЫ И ПЕРСПЕКТИВЫ}

Рынок страхования жизни в каждой стране является индикатором экономики и устойчивого развития предпринимательства. Когда стабильность и благополучие страны достигает определенного уровня, то и работники, и работодатели начинают думать о своем будущем, обеспечивать свою старость, финансировать риски, которые существуют в жизни каждого человека. Стремительное старение населения всех стран мира истощзает финансовую состоятельность граждан, что приводит к низкому уровню здравоохранения и пенсионного обеспечения. Страхование жизни позволяет обеспечить ежедневную защчиту человека - как сегодня, так и в будущем. Это приводит к возникновению двух эффектов: у государства появляются дополнительные долгосрочные средства, которые обеспечивают финансирование инвестиционных проектов, что способствует дальнейшему развитию экономики страны; граждане получают страховую защиту, накопления на будущие периоды и защиту интересов. Рынок страхования жизни в Украине находится на этапе формирования. Основныли препятствиями и проблемами его развития являются нестабильная социально-экономическая ситуация на современном этапе и особенности культурно-исторических традиций украинского общества.

Ключевые слова: рынок страхования, страхование, страхование жизни, соииальная система, тендениии, динамика. 


\section{LIFE INSURANCE IN UKRAINE: PROBLEMS AND PROSPECTS}

A market of life insurance in every country is the indicator of economy and steady development of enterpreneuship. When stability and welfare of any country reach certain level, workers and employers begin to think of the future (retirement, finance risks). Life-insurance gives an opportunity to provide daily defence of an individed-both today, and in the future. A market of life insurance in Ukraine is forming now. Basic obstacles and problems of it's development are unstable social and economic situation. Therefore, even with substantial changes in a legislative base, the market of life insurance occupies a weak point in an economy and needs changes and government control, namely: strengthening of legal and economic mechanisms of defence of interests of insure and stimulation of population and employers for insurence; creation of principles for the association of the insurance and pension systems in Ukraine. Insurance is a means of protection from financial loss. It is a form of risk management, primarily used to hedge against the risk of a contingent or uncertain loss. On the basis of the conducted analysis of insurance coverage we educed the positive and negative moments of insurance legislation in Ukraine. The questions that need a decision are: association of life-insurance with other types of insurance (medical and pension); increase of sources of profits of insurer; financial providing of compensation of accidents insured; a question of equity fund of insurer is minimum charter fund; an input of tax deductions. Functioning of insurance company complex analysis that consists of three stages reflects the: analysis of the financial provision of; analysis of investment activity; estimation of efficiency of activity of such companies. Development of life-insurance in Ukraine predetermines the search of directions of his improvement: the insufficient level of equity fund of insurers; entering of Ukraine into WTO, that is why calculations and recommendations are given in relation to the increase of size of charter capital of insurers. Not the investigational enough is remained by the problem of the pension system through the programs of long-term life-insurance in insurance companies. It is well-proven that terms and performance of insurance companies indicators exceed the indexes of non-state funds. It is suggested to extend directions of investment activity and more detailed to learn investment activity in the sphere of deposit contributions to bank institutions.

Key words: market insurance, insurance, life insurance, social system, trends, dynamics. 